\title{
HOC VOLVMINE CONTINENTVR
}

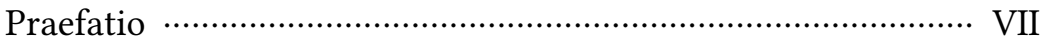

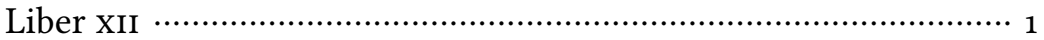

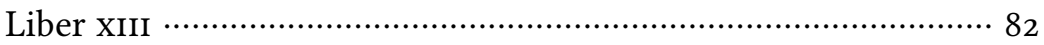

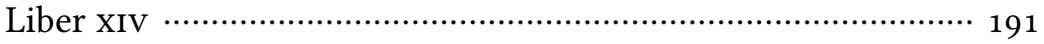

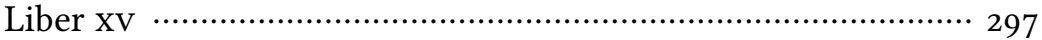

Epitome

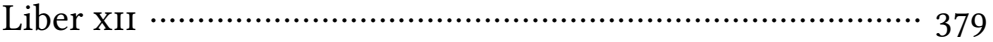

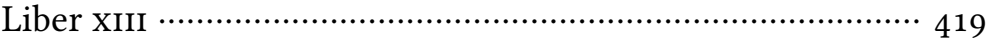

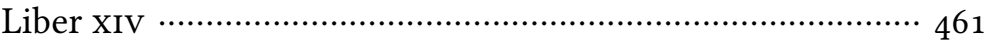

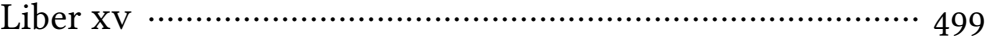


